\title{
PENERAPAN MODEL PEMBELAJARAN ADI (ARGUMENT DRIVEN INQUIRY) PADA KONSEP GARAM TERHIDROLISIS
}

\author{
Erna Dwi Susanti*, Riri Aisyah, Cucu Zenab Subarkah \\ Prodi Pendidikan Kimia, Fakultas Tarbiyah dan Keguruan, Universitas Islam \\ Negeri Sunan Gunung Djati, Bandung \\ Email : ernadwi30@gmail.com
}

\begin{abstract}
The purpose of this study is to describe the activities of students during the learning process using the ADI model and analyze the ability of students to complete the ADI-based LKS on the concept of hydrolyzed salt. The method used in this research is class research with the design of one shoot case study. The subjects of this study were students of class XI IPA 4 in one of the 16 SMA Negeri Bandung, amounting to 37 people. The research instruments used were observation sheets, worksheets, and practicum report assessment rubrics. The results showed that student activity during learning using the ADI model reached an average of $91 \%$ and was categorized very well. The results of the research on the completion of ADI-based LKS reached an average of 73 and were categorized well, with the highest average value at the stage of revising the report, which was 82. The results were obtained due to the existence of inquiry activities during the practicum and argumentation activities. Thus the ADI learning model can improve student activity and students' ability to complete ADI-based LKS on the concept of hydrolyzed salt.
\end{abstract}

Key Words : ADI Learning Model, Hydrolyzed Salt

\begin{abstract}
Abstrak
Tujuan penelitian ini untuk mendeskripsikan aktivitas siswa selama proses pembelajaran menggunakan model ADI dan menganalisis kemampuan siswa menyelesaikan LKS berbasis ADI pada konsep garam terhidrolisis. Metode yang digunakan dalam penelitian ini adalah penelitian kelas dengan desain one shoot case study. Subyek penelitian ini adalah siswa kelas XI IPA 4 di salah satu SMA Negeri 16 Kota Bandung yang berjumlah 37 orang. Instrumen penelitian yang digunakan yaitu lembar observasi, LKS, dan rubrik penilaian laporan praktikum. Hasil penelitian menunjukkan bahwa aktivitas siswa selama pembelajaran menggunakan model ADI mencapai rata-rata $91 \%$ dan dikategorikan sangat baik. Hasil penelitian dari penyelesaikan LKS berbasis ADI mencapai rata-rata 73 dan dikategorikan baik, dengan nilai rata-rata tertinggi pada tahap merevisi laporan yaitu 82. Hasil diperoleh disebabkan karena adanya kegiatan inkuiri saat praktikum dan kegiatan argumentasi. Dengan demikian model pembelajaran ADI dapat meningkatkan aktivitas siswa dan kemampuan siswa menyelesaikan LKS berbasis ADI pada konsep garam terhidrolisis.

Kata Kunci : Model Pembelajaran ADI, Garam terhidrolisis
\end{abstract}




\section{PENDAHULUAN}

Ilmu kimia adalah rumpun dari ilmu pengetahuan Alam. Kimia sering dianggap lebih sulit untuk dipahami oleh peserta didik karena memiliki banyak kata yang sangat khusus dan beberapa konsepnya yang bersifat abstrak (Chang, 2005:4). Salah satu konsep kimia yang dianggap sulit untuk dipahami yaitu konsep garam terhidrolisis. Pada konsep ini membahas mengenai reaksi ionisasi garam yang terlarut dalam air (Maikristina, dkk., 2013:1). Reaksinya tidak dapat dilihat dengan kasat mata atau bersifat abstrak. Pada pembelajarannya siswa tidak hanya dituntut untuk mengetahui sifat larutan garam, dan siswa juga mampu menjelaskan mengapa larutan garam tersebut dapat bersifat asam, basa, netral serta perhitungan $\mathrm{pH}$ larutan berdasarkan hubungan $\mathrm{Ka}, \mathrm{Kb}$, $\mathrm{Kh}$ dan $\mathrm{Kw}$ (Maikristina, dkk., 2013:2).

Berdasarkan studi pendahuluan, permasalahan yang ditemukan yaitu peserta didik mengalami kesulitan pada pembelajaran garam terhidrolisis karena materi ini bersifat abstrak dan kompleks yang membutuhkan pemahaman konsep dan pemahaman algoritma seperti menentukan rumus garam terhidrolisis. Hasil penelitian Khoiriyah dalam Boncel, dkk., (2010:1) kesulitan siswa dalam menyelesaikan soal garam terhidrolisis diperoleh: 1) Siswa yang mengalami kesulitan dalam memahami pengertian garam terhidrolisis sebanyak 40,9\%; 2) Siswa yang mengalami kesulitan dalam menentukan jenis garam terhidrolisis sebanyak 51,3\%; 3) Siswa yang mengalami kesulitan dalam menentukan garam yang terhidrolisis sebanyak $23,4 \%$; 4) Siswa yang mengalami kesulitan dalam menuliskan persamaan reaksi hidrolisis garam sebanyak 41,9\%; 5) Siswa yang mengalami kesulitan dalam menentukan sifat larutan hasil garam terhidrolisis sebanyak 52,3\%. Siswa yang mengalami kesulitan dalam menentukan rumus mencari $\left[\mathrm{H}^{+}\right]$dan $\left[\mathrm{OH}^{-}\right]$dari persamaan reaksi garam terhidrolisis sebanyak $54,2 \%$; 7) Siswa yang mengalami kesulitan dalam menggunakan rumus $\mathrm{pH}$ untuk menentukan nilai $\mathrm{pH}$ larutan garam terhidrolisis sebanyak 46,8\%.

Selain itu, kesulitan siswa dalam memahami konsep garam terhidrolisis karena berkaitan dengan reaksi-reaksi kimia yang tidak memberikan contoh konkrit dalam kehidupan sehari-hari. Sehingga siswa kurang memahami konsep 
dan tidak bisa memberi penjelasan dan gagasannya padahal konsep ini erat kaitannya dengan kehidupan sehari-hari. Oleh sebab itu, dibutuhkan pemahaman konsep siswa dengan melibatkan kegiatan praktikum dan kegiatan argumentasi. Kegiatan praktikum akan memberikan peran yang sangat besar dalam membangun pemahaman konsep, memverifikasi atau membuktikan kebenaran konsep, serta menumbuhkan keterampilan proses serta afektif siswa (Yunita, 2010:10).

Oleh karena itu, diperlukan alternatif model pembelajaran instruksional yang menekankan peran argumentasi dan penyelidikan dalam pendidikan sains (Demircioglu \& Ucar, 2015:268). Salah satu model pembelajaran yang dapat diterapkan pada konsep garam terhidrolisis yaitu ADI (Argument Driven Inquiry). Model pembelajaran ADI berbeda dengan model pembelajaran inkuiri karena model pembelajaran ADI terintegrasi dengan kegiatan argumentasi yang dapat membantu siswa untuk memahami bagaimana cara membuat penjelasan secara ilmiah, bagaimana menggeneralisasikan fakta ilmiah, menggunakan data untuk menjawab pertanyaan penelitian dan dapat merefleksikan hasil penyelidikan yang telah dilakukan (Sampson, et al., 2010:224). Model pembelajaran ADI bersumber dari teori konstruktivis sosial dan diharapkan dapat meningkatkan berpikir kritis serta keterampilan penalaran melalui inkuiri berbasis aktivitas pratikum melalui kerja kelompok (Walker \& Sampson, 2013: 562). Model pembelajaran ADI memberikan kesempatan siswa untuk mengembangkan pendekatan saintifik yang bertujuan mengumpulkan data, mendesain dan melakukan penyelidikan, menggunakan data yang diperoleh untuk menjawab pertanyaan penelitian dan review teman sebaya (Walker, et.al., 2011: 1052).

Berbagai penelitian mengenai penerapan model pembelajaran ADI sudah banyak dilakukan, salah satunya penelitian yang dilakukan Farida \& Gustiarti bahwa penerapan model pembelajaran inkuiri argumentatif pada konsep koloid dapat meningkatkan keaktifan siswa, pengembangan keterampilan argumentasi siswa, dan pengembangan karakter ilmiah siswa (Farida \& Gusniarti, 2014:31). Penelitian lain yang dilakukan penelitian Patmi, dkk menyimpulkan bahwa efektifitas model pembelajaran ADI (Argument Driven Inquiry) dapat 
meningkatkan pengusaan konsep materi zat aditif dan adiktif ditinjau berdasarkan gender siswa, hal ini sesuai dengan hasil penelitiannya rata-rata n-Gain penguasaan konsep siswa kelas eksperimen secara signifikan lebih tinggi daripada kelas kontrol,baik secara umum maupun dari gender (Patmi, dkk., 2018:1).

Selain itu, penelitian yang dilakukan Kalay, dkk menyimpulkan pembelajaran remidi model ADI lebih efektif dalam meningkatkan jumlah siswa yang paham konsep (dari 5,2 menjadi 71,2\%), dibandingkan model konvensional (dari 13,2 menjadi 65,5\%). Hasil perbaikan konsep dengan model ADI tersebut juga mempunyai resistensi yang tinggi $(95,5 \%)$, lebih tinggi dibanding retensi hasil pembelajaran konvensional (82,4\%) (Kalay, Subandi, \& Budiasih, 2015). Penelitian yang dilakukan oleh Setiawan (2013:86) menyimpulkan bahwa model ADI pada konsep kesetimbangan hasil kelarutan dapat meningkatkan keaktifan siswa, kemampuan hasil belajar dan mengembangkan karakter siswa pada konsep yang dipelajari.

Adapun keterbaruan pada penelitian ini ialah bertujuan untuk memperoleh informasi mengenai: (1) aktivitas siswa pada pembelajaran ADI dan (2) kemampuan siswa dalam menyelesaikan Lembar Kerja Siswa berbasis ADI pada konsep garam terhidrolisis.

\section{METODE PENELITIAN}

Metode yang digunakan yaitu penelitian kelas dengan desain one-shot case study. Penelitian dengan one-shot case study yaitu penelitian yang dilakukan hanya dengan satu kelas yang diberi perlakuan yang selanjutnya diobservasi hasilnya (Sugiyono, 2011:109). Model yang digunakan adalah model ADI dengan 8 tahapan pembelajaran yaitu identifikasi tugas dan pertanyaan inkuiri, mengumpulkan data, membuat argumen tentatif, sesi argumen, menulis laporan, double blind group peer review, revisi laporan, dan diskusi eksplisit dan reflektif. Berikut skema pembelajaran ADI: 


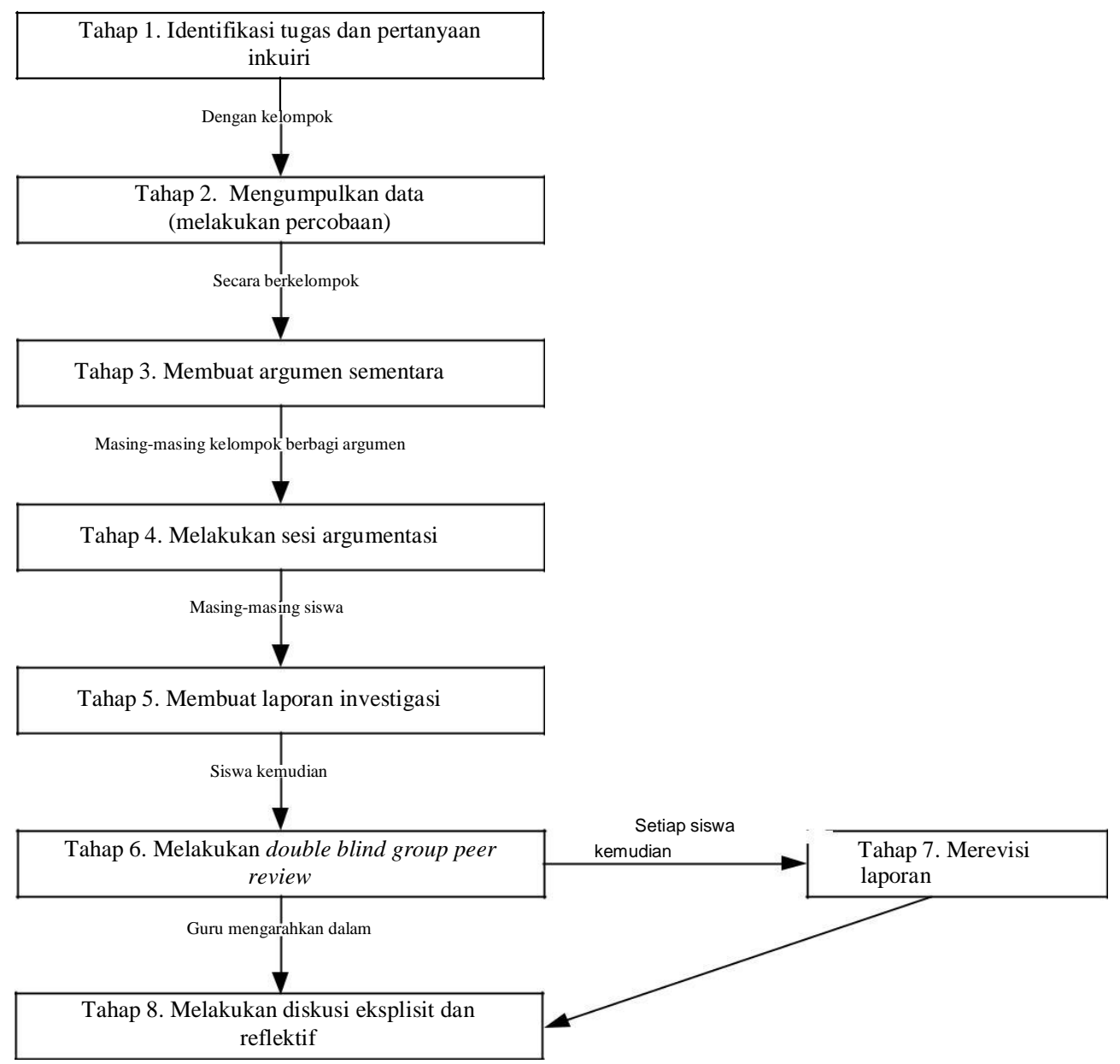

Gambar 1. Tahapan model pembelajaran ADI

(Sampson \& Gleim, 2009:466)

Subjek penelitian ini yaitu siswa kelas XI di salah satu SMA Negeri Kota Bandung yang berjumlah 37 siswa semester genap tahun ajaran 2017/2018. Siswa yang berjumlah 37 orang ini dikelompokkan berdasarkan prestasi belajar yang terdiri dari siswa kelompok tinggi, sedang dan rendah. Adapun waktu penelitian dilaksanakan dar bulan Maret 2018 hingga April 2018.

Tahapan penelitian dimulai dari tahap persiapan, tahap pelaksanaan dan tahap akhir. Instrumen penelitian yang digunakan yaitu lembar observasi, LKS, dan rubrik penilaian laporan praktikum. Data aktivitas siswa diperoleh melalui kegiatan observasi selama proses pembelajaran. Sementara data kemampuan siswa menyelesaikan LKS berbasis ADI deperoleh melalui analisis penyelesaian LKS. 
HASIL DAN PEMBAHASAN

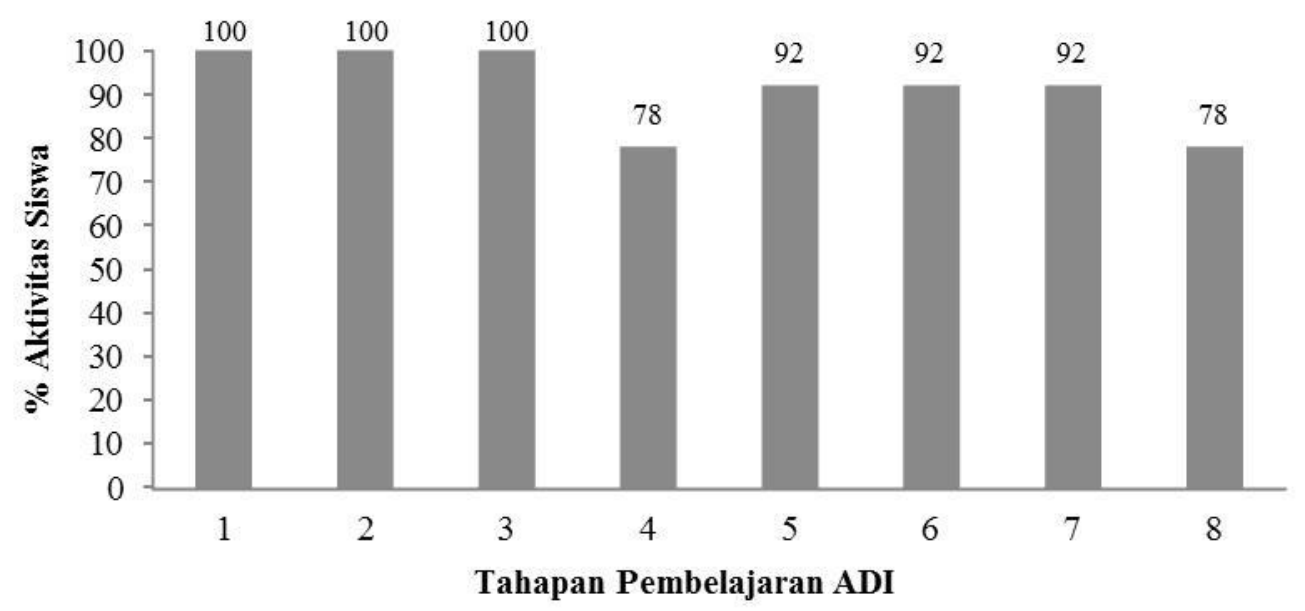

Gambar 2. Persentase aktivitas kelompok siswa untuk setiap tahapan pembelajaran ADI

Gambar 2 menunjukkan bahwa hasil observasi aktivitas siswa merujuk pada predikat keaktifan (Purwanto, 2009). Keaktifan untuk tahap 1 sampai tahap 8 dikategorikan sangat baik. Adapun tahap-tahap pembelajaran ADI adalah: (1) tahap 1: identifikasi tugas dan pertanyaan inkuiri, (2) tahap 2: mengumpulkan data, (3) tahap 3: membuat argumen tentatif, (4) tahap 4: adu argumen, (5) tahap 5: menulis laporan, (6) tahap 6: double blind group peer review (7) tahap 7 : revisi laporan, (8) tahap 8: diskusi eksplisit dan reflektif. Jika dirata-ratakan, persentase keaktifan siswa untuk keseluruhan tahapan pembelajaran ADI adalah 91\% dengan kategori keaktifan sangat baik. Hal ini menujukkan bahwa pembelajaran ADI dapat meningkatkan keaktifan siswa. Hal ini sejalan dengan hasil penelitian Andriani \& Robin (2015:592) bahwa penerapan model pembelajaran ADI merupakan model yang dapat meningkatan aktivitas siswa diantaranya mengembangkan keaktifan siswa, penguasaan konsep maupun kemampuan argumentasi siswa. 


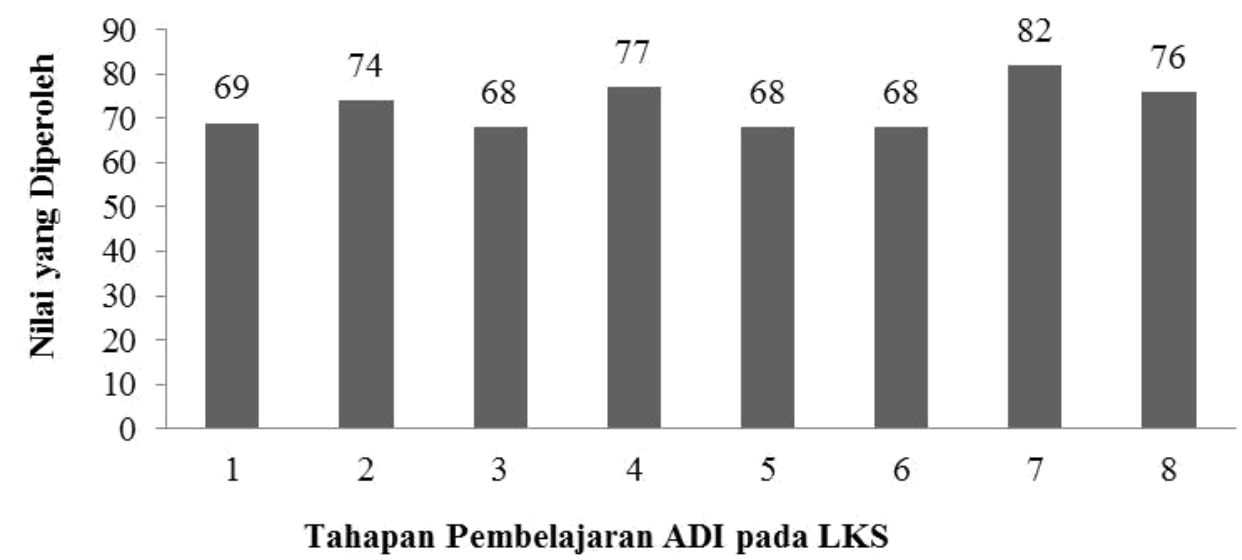

Gambar 3. Nilai penyelesaiaan LKS berbasis ADI pada semua tahapan pembelajaran ADI

Kemampuan siswa dalam menyelesaikan LKS berbasis ADI dapat dilihat pada Gambar 3. Gambar tersebut menunjukkan bahwa nilai rata-rata LKS tertinggi ditemukan pada tahap 7 yaitu merevisi laporan sedangkan nilai rata-rata terendah ditemukan pada tahap ketiga dan kelima yaitu membuat argumen sementara dan menulis laporan. Jika dirata-ratakan, nilai rata-rata LKS berbasis ADI yang diperoleh siswa adalah 73 dan dikategorikan baik.

Adapun indikator pembelajaran pada tahap 1 yakni siswa dapat menjawab pertanyaan inkuiri yang terdapat dalam LKS. Siswa diberikan pertanyaan penyelidikan yang terdapat dalam wacana garam terhidrolisis "Apakah semua larutan garam memiliki sifat yang sama?" Berdasarkan Gambar 3. hasil penilaian penyelaian LKS pada tahap 1 adalah 69. Hal ini menunjukkan bahwa siswa dapat menyelesaikan dengan kategori cukup. Pertanyaan inkuiri yang diajukan pada LKS merupakan bagian dari proses pembelajaran yang ditujukan untuk menggali pengetahuan awal dan mendorong keingintahuan siswa untuk menyelesaikan permasalahan (Sampson \& Gleim, 2009: 464).

Indikator pembelajaran pada tahap 2 yakni siswa dapat mengumpulkan dan menganalisisis data melalui praktikum dan diskusi kelompok. Siswa diarahkan mengidentifikasi alat dan bahan percobaan, merancang prosedur percobaan, melakukan kegiatan praktikum, mencatat hasil pengamatan serta menginterpretasi pertanyaan yang terdapat dalam LKS garam terhidrolisis. 
Berdasarkan Gambar 3. hasil penilaian LKS tahap 2 adalah 74 dan dikategorikan baik. Sedangkan nilai rata-rata kemampuan kinerja siswa secara keseluruhan adalah 100 dan dikategorikan sangat baik. Hal ini disebabkan karena siswa sangat antusias dalam melakukan praktikum garam terhidrolisis sehingga rasa ingin tahu siswa untuk melakukan penyelidikan ilmiah sangat tinggi dan untuk mengasah keterampilan argumentasi. Sejalan dengan yang dikemukakan oleh Yunita (2010) kegiatan praktikum akan memberikan peran yang sangat besar dalam membangun pemahaman konsep, memverifikasi atau membuktikan kebenaran konsep, serta menumbuhkan keterampilan proses serta afektif siswa. Selain itu kegiatan praktikum juga dapat menunjang kreatifitas dan semangat siswa untuk belajar. Siswa mampu menemukan hal-hal baru yang belum pernah dilakukannya sebelumnya. Siswa tidak hanya sekedar mengetahui teorinya saja tetapi siswa juga ikut menyaksikan secara langsung yang mampu memberikan pengalaman (Desriyanti \& Lazulva, 2016:77)

Indikator pembelajaran pada tahap 3 yakni siswa dapat membuat argumen sementara dari pertanyaan penyelidikan yang terdapat dalam wacana garam terhidrolisis. Siswa diarahkan untuk membuat argumen sementara dilembar argumen tentatif. "Apakah semua jenis garam memilki sifat yang sama dengan garam dapur?" kemudian dikaitkan dengan data dan fakta hasil pecobaan garam terhidrolisis menggunakan kertas lakmus. Pada tahap ini siswa dituntut agar dapat mengembangkan keterampilan argumentasi ilmianya secara tertulis. Berdasarkan Gambar 3. hasil penilaian penyelesaian LKS pada tahap 3 adalah 68 dan dikategorikan cukup. Nilai rata-rata terendah yaitu pada tahap ini karena siswa mengalami kesulitan untuk membuat argumen sementara. Salah satu faktor yang menyebabkan pembuatan argumen tentatif cukup karena siswa kurang memunculkan ide atau gagasannya terhadap pertanyaan penelitian yang diberikan. Menurut Walker, et al., (2011:1050) dalam membuat argumen tentatif harus memunculkan ide-ide, bukti dan penalaran sehingga mencerminkan siswa dapat berargumentasi secara ilmiah.

Indikator pembelajaran pada tahap 4 yakni siswa dapat melaksanakan kegiatan adu argumen berdasarkan argumen tentatif yang telah dibuat. Siswa 
diminta untuk mempersentasikan argumen tentatifnya dan yang lainnya saling membantu dan menjawab pertanyaan serta berpendapat. Sebagian siswa menjawab bahwa semua garam tidak memiliki sifat sama melainkan bersifat netral, asam maupun basa. Berdasarkan Gambar 3. hasil penilaian LKS tahap 4 adalah 77 dan dikategorikan baik. Melalui kegiatan adu argumen, siswa dapat melatih berkomunikasi dan menciptakan argumen dengan baik. Hal ini sejalan dengan yang dikemukakan Delioglu dalam Pritasari, dkk. (2016:3) bahwa kemampuan menjelaskan dan memberi pembenaran berdsasaran pernyataan yang didukung oleh data merupakan bagian dari menciptakan argumen.

Indikator pembelajaran pada tahap 5 yakni siswa dapat menuliskan laporan ilmiah berdasarkan percobaan penentuan sifat dan $\mathrm{pH}$ larutan garam. Siswa diarahkan untuk membuat laporan ilmiah berdasarkan hasil percobaan dan kegiatan argumentasi. Adanya kegiatan menulis laporan pada model pembelajaran ADI ini dapat membantu siswa belajar untuk mempertahankan konsep-konsep atau prinsip penting dalam sains (Indrisano dalam Sampson \& Gleim, 2009:470). Berdasarkan Gambar 3. hasil penilaian LKS pada tahap 5 yaitu 68 dan dikategorikan cukup. Tahap ini merupakan nilai rata-rata terendah kedua dari tahap yang lain. Hal ini disebabkan karena siswa kurang menggunakan sumber pustaka, sehingga masih kurang dalam membahas hasil percobaan dan kesimpulan yang dibuatnya kurang tepat. Kemampuan menulis harus ditunjang dengan aktivitas membaca dan mendengarkan, karena berbagai informasi yang dibutuhkan terkait hasil percobaan bisa didapatkan melalui membaca dan mendengarkan (Rosidi, 2009:3).

Pada tahap 6 indikator yang dikembangkan adalah siswa dapat mengumpulkan dan memeriksa laporan yang telah dibuat temannya. Berdasarkan Gambar 3. Hasil penilaian LKS pada tahap ini yaitu 68 dan dikategorikan cukup. Pada tahap ini siswa belajar mengenai bagaimana sulitnya melakukan penilaian. Mereka juga bisa membandingkan laporan yang telah mereka buat sendiri dengan laporan temannya. Penilaian yang dilakukan, harus dianalisis secara seksama dengan pedoman penskoran agar menghasilkan nilai yang sesuai dengan isi laporan tersebut. 
Indikator pembelajaran pada tahap 7 yakni siswa dapat merevisi laporan berdasarkan sanggahan yang diberikan oleh pemeriksa. Tujuannya yaitu untuk mendorong siswa untuk memperbaiki tulisan berdasarkan umpan balik edukatif (Farida \& Gusniarti, 2014: 36). Pada Gambar 3. hasil penilaian LKS pada tahap ini yaitu 82 dan dikategorikan sangat baik. Tahap ini merupakan nilai rata-rata tertinggi. Hal tersebut disebabkan karena siswa telah diberi kesempatan untuk memperbaiki laporan hasil penyelidikan yang telah diberi tanggapan oleh temannya. Sehingga melalui tahap revisi laporan kemampuan argumentasi siswa dapat meningkat karena tidak hanya berargumen secara ilmiah namun siswa juga dapat menganalisis argumen dengan baik (Marhamah, dkk. 2017:51).

Indikator pembelajaran pada tahap 8 yakni siswa dapat menjelaskan kembali konsep garam terhidrolisis yang telah diperoleh. Ketika peneliti mengajukan pertanyaan sebagian besar siswa mengangkat tangan untuk menjawab. Hal ini menjadi indikator bahwa siswa sudah dapat menerima materi garam terhidrolisis dengan baik, namun ada beberapa siswa yang kurang antusias terhadap pertanyaan yang diberikan. Berdasarkan Gambar 3. hasil penyelesaian LKS pada tahap ini yaitu 76 dan dikategorikan baik. Dengan demikian model pembelajaran ADI merupakan pembelajaran yang terintegrasi dengan kegiatan argumentasi yang dapat membantu siswa untuk memahami bagaimana cara membuat penjelasan secara ilmiah, bagaimana menggeneralisasikan fakta ilmiah, menggunakan data untuk menjawab pertanyaan penelitian dan dapat merefleksikan hasil penyelidikan yang telah dilakukan ( Sampson, et al., 2010:224).

\section{KESIMPULAN}

Model pembelajaran ADI memberikan pengaruh terhadap keaktifan siswa dan kemampuan siswa dalam menyelesaikan LKS berbasis ADI. Masih rendahnya kemampuan siswa dalan kegiatan adu argumen menunjukkan bahwa perlu dilatih secara terus-menerus agar terbiasa mengutarakan pendapat. 


\section{DAFTAR PUSTAKA}

Andriani, Y., \& Robin, R., 2015, Perbandingan Aktifitas Siswa dan Guru dalam Pembelajaran Argument Driven Inquiry dan Inkuiri Terbimbing pada Pembelajaran IPA Terpadu Kelas VII, (Snips), 589-592.

Boncel, W., Enawaty, E., \& Sartika, R. P., 2010, Deskripsi Kesalahan Siswa Dalammenyelesaikan Soal-Soal Hidrolisis Garam Di Kelas XI IPA SMA Katolik Talino. Jurnal Ilimiah Universitas Tanjungpura, 1-7.

Chang, R., 2005, Kimia Dasar: Konsep-konsep Inti Jilid 2 Edisi Ketiga, Erlangga, Jakarta.

Demircioglu, T., \& Ucar, S., 2015, Investigating the Effect of Argument-Driven Inquiry in Laboratory Instruction, Kuram ve Uygulamada Egitim Bilimleri, 15(1), 267-283.

Desriyanti, R., \& Lazulva., 2016, Penerapan Problem Based Learning Pada Pembelajaran Konsep Hidrolisi Garam Untuk Meningkatkan Hasil Belajar, Jurnal Tadris Kimiya, 1(2), 70-78.

Farida, \& Gusniarti, W. F., 2014, Profil Keterampilan Argumentasi Siswa Pada Konsep Koloid Yang Dikembangkan Melalui Pembelajaran Inkuiri Argumentatif, EduSains, 6(1), 31-40.

Kalay, B. A., Subandi, \& Budiasih, E., 2015, Efektifitas Model Pembelajaran Argument Driven Inquiry (ADI) Dalam Meningkatkan Pemahaman Konsep Siswa Pada Materi Bentuk Dan Kepolaran Molekul, Jurnal Ilmu Pendidikan, 23(2), 117-125.

Maikristina, N., Dasna, I. W., \& Sulistina, O., 2013, Pengaruh Penggunaan Model Pembelajaran Inkuiri Terbimbing terhadap Hasil Belajar dan Keterampilan Proses Sains Siswa Kelas XI IPA SMAN 3 Malang pada Materi Hidrolisis Garam, Jurnal Kimia FMIPA UNM, 1, 1-8.

Marhamah, O. shofiyatun, Nurlaelah, I., \& Setiawati, I., 2017, Penerapan Model Argument Driven Inquiry (ADI) dalam Meningkatkan Kemampuan Beragumentasi Siswa pada Konsep Pencemaran Lingkungan di Kelas X SMA Negeri 1 Ciawigebang, Quagga, 9(2), 46-54.

Patmi, C. M., Kadaritna, N., \& Tania, L., 2018, Efektivitas Model ADI terhadap Penguasaan Konsep Materi Zat Aditif dan Adiktif Ditinjau dari Gender, Jurnal Pendidikan Dan Pembelajaran Kimia, 7(2), 1-14.

Pritasari, A. C., Dwiastuti, S., \& Probosari, R. M., 2016, Peningkatan Kemampuan Argumentasi melalui Penerapan Model Problem Based Learning pada Siswa Kelas X MIA 1 SMA Batik 2 Surakarta Tahun Pelajaran 2014/2015, Pendidikan Biologi, 8(1), 1-7.

Purwanto, N., 2009, Prinsip dan Teknik Evaluasi Pengajaran, Remaja Rosdakarya, Bandung.

Rosidi, I., 2009, Menulis Siapa Takut. Kanisius, Yogyakarta. 
Sampson, V., \& Gleim, L., 2009, Argument-Driven Inquiry To Promote the Understanding of Important Concepts \& Practices in Biology, The American Biology Teacher, 71(8), 465-472.

Sampson, V., Grooms, J., \& Walker, J. P., 2010, Argument-Driven Inquiry as a way to Help Students Learn How to Participate in Scientific Argumentation and craft Written Arguments: An Exploratory Study, Science Education, 95(2), 217-257.

Setiawan, I., 2013, Penerapan Model Pembelajaran ADI (Argument Driven Inquiry) Pada Konsep Kelarutan dan Hasil Kelarutan, UIN Sunan Gunung Djati Bandung.

Sugiyono, 2011, Metode Penelitian Kuantitatif Kualitataif dan $R \& D$, Alfabeta, Bandung.

Walker, J. P., \& Sampson, V., 2013, Learning to Argue and Arguing to Learn: Argument-Driven Inquiry as a Way to Help Undergraduate Chemistry Students Learn How to Construct Arguments and Engage in Argumentation During a Laboratory Course, Journal of Research in Science Teaching, 50(5), 561-596.

Walker, J. P., Sampson, V., \& Zimmerman, C. O., 2011, Argument-Driven Inquiry: an Introduction to a New Instructional Model for Use in Undergraduate Chemistry Labs, Journal of Chemical Education, 88(8), $1048-1056$.

Yunita, 2010, Panduan Pengelolaan Laboratorium Kimia, Insan Mandiri, Bandung. 